\title{
Adaptation to Precarious Prosperity: Is it Resignation?
}

\author{
Rebekka Sieber*
}

Abstract: This article aims at understanding how adaptation occurs in precarious prosperity. It investigates quality of life in Switzerland using a longitudinal qualitative design. The results show that processes of adaptation tend to be similar according to relevant social experiences and that adaptation does not mean complete resignation. Furthermore, the reasoning of adapting people changes over time. This shows an internalization of the perceived norm not being satisfied. Adaptation thus contributes to the reproduction of inequalities on a societal level. Keywords: adaptation, precarious prosperity, quality of life, agency

\section{Anpassung an prekären Wohlstand - ein Anzeichen für Resignation?}

Zusammenfassung: Ziel dieser Analyse ist es, Adaptationsprozesse und Lebensqualität in prekärem Wohlstand in der Schweiz besser zu verstehen. Mit einer qualitativen Längsschnittanalyse wird erarbeitet, wie spezifische Adaptationsprozesse mit als relevant wahrgenommenen sozialen Erfahrungen einhergehen und dass Adaptation nicht mit Resignation gleichzusetzen ist. Weiter zeigt die Analyse, wie die wahrgenommene Norm, zufrieden sein zu müssen, mit der Zeit internalisiert wird. Insofern trägt Adaptation zur Reproduktion von sozialen Ungleichheiten bei.

Schlüsselwörter: Anpassung, prekärer Wohlstand, Lebensqualität, Agency

\section{Adaptation à la prospérité précaire - est-ce une résignation ?}

Résumé: Par une analyse qualitative et longitudinale, cet article cherche à comprendre les processus d'adaption et leur impact sur la qualité de vie des personnes en situation de prospérité précaire en Suisse. Les processus d'adaptation sont liés aux expériences sociales que ces personnes perçoivent comme importantes, mais ne peuvent pas être assimilés à une resignation complète de leur part. De plus, leurs réflexions liées à l'adaptation évoluent avec le temps, ce qui montre une intériorisation de leurs perceptions liées à la satisfaction. Ainsi, l'adaptation contribue à la reproduction des inégalités sociales.

Mots-clés: adaptation, prosperité précaire, qualité de vie, agency

University of Neuchâtel; University of Fribourg, Soziologie, Sozialpolitik und Sozialarbeit, CH-1700 Fribourg, rebekka.sieber@unifr.ch. 
In light of welfare-state retrenchment and times of crisis, households at risk of slipping into poverty have become a largely debated topic in scientific research. These households, here defined as being in precarious prosperity, are not a target group of social policy as such. Studying adaptation in precarious prosperity is even more crucial for welfare research, as, according to Zapf (1984), people who are adapted to their living conditions reveal a reality of powerlessness and are often not reached by social-policy measures. Despite the 40 -year-old debate on adaptation, "empirical evidence of how exactly the quality of life and poverty indicators are affected by these processes is still surprisingly scarce" (Crettaz and Suter 2013, 140). Carol Graham, who has been working on adaptation with a quantitative and international approach, notes:

\begin{abstract}
Adapting expectations downward in difficult contexts or at times of adversity, such as economic crises or rising rates of crime, seems to be a useful trait for preserving individual happiness in the face of major challenges. At the same time, it can result in lower collective welfare levels by increasing tolerance for bad equilibriums, such as high levels of crime and corruption or dysfunctional governments. (Graham 2009, 215)
\end{abstract}

The present research links precarious prosperity to quality of life (QOL) and adaptation. My question is: What happens over time in adaptation to precarious prosperity and what reasonings go along with these processes?

Precarious prosperity describes a specific welfare position within the inequality order, which lies between poverty and secure prosperity. This stratum is characterized by a limited standard of living. It was originally developed by Hübinger (1996) and refined by Budowski et al. (2010). The topic of precarious prosperity is linked to debates on precariousness and vulnerability (Bankoff 2001; Castel and Dörre 2009). Research on households around the poverty line in Switzerland was first quantitative (Mayer 1975; Schulte 1999; Tillmann and Budowski 2004; Farago et al. 2005). Similarly, longitudinal research on precarious prosperity and well-being is only quantitative (Tillmann et al. 2016). Qualitative and comparative research on precarious prosperity has begun to address the aspects of QOL and adaptation (Budowski et al. 2016; Sieber and Vlase 2016). The results show that the ways in which opportunities provided by the state, the labor market, the community, and the household are perceived influence the strategies that households apply to improve or maintain their socioeconomic positions.

1 The Swiss National Science foundation funded this research (SNF Grants: no. 116605 and no. IZERZO 141975). I thank the teams at the University of Fribourg and the University of Neuchâtel for their contributions to the data collection, transcription and coding. I also thank the reviewers for their precious feedback. 
QOL in this research is distinguished from subjective well-being (SWB) and considers the latter to be the "happiness" or "satisfaction" of the individual. QOL is assessed by socioeconomic living conditions in various life domains ${ }^{2}$ and people's evaluation thereof (Noll 1999; Stiglitz et al. 2009). Structural and biographical events change living conditions; additionally, research highlights the importance of past experiences, present opportunities (Felce and Perry 1995), and the future (Piper 2014) with regard to the perception of opportunities to improve QOL. According to Zapf (1984), QOL is defined here as good living conditions that accompany positive subjective well-being. Quantitative research on QOL is a well-established field of social science around the world (Noll 2002). However, longitudinal qualitative research on the topic is scant.

Adaptation concerns the process by which a person becomes insensitive to the effects of constant stimuli (Helson 1964). In psychology, the small correlations between subjective well-being and objective conditions have been discussed for several decades, using concepts such as social comparison (Festinger 1954), level of aspiration (Lewin et al. 1944), or reappraisal (Sirgy 2002). Adaptation is also a research field in economy (Ray 2003), anthropology (Appadurai 2004), and philosophy (Elster 1982).

In sociology, adaptation is discussed as the capacity to act according to the norms, demands, and constraints of a given community or environment (e.g., adaptation to climate change). There is quantitative research on adaptation linked to QOL and subjective well-being: Easterlin (1974) first observed that the association between happiness and income over time and across countries is weak, suggesting that adaptation might be the mechanism at play. Since then, quantitative researchers have challenged the observation that people adapt to their living conditions (Veenhoven and Vergunst 2012). Scholars present methodological or behavioral reasons to explain adaptation in subjective well-being as generally measured in Western countries and the way in which it relates to living conditions. The former concern difficulties in the measurement of objective and subjective well-being variables, and the latter concerns the influences of culture and desirability on the expression of satisfaction (Olson and Schober 1993, 176). Qualitative researchers have effectively observed that adaptation leads to high subjective well-being, e.g., with analyses of precarious work (Grimm et al. 2013) and health (Helvik et al. 2011).

Zapf (1984) describes the state of adaptation (Table 1), and this description is a starting point for analyzing the processes leading to adaptation; this state was empirically found among individuals living in precarious prosperity in former analyses of the data used in this article. The objective of this article is to understand the processes that lead to this state of adaptation.

2 The growing literature on each of these domains (e.g. health related QOL) can't be developed here. 
Lister's (2004) and Schütz's (1932) theoretical approaches are used to analyze what leads to the state of adaptation. Longitudinal qualitative data analysis allows for the reconstruction and interpretation of the interviewees' perception or their past and present experiences within their household contexts, and of their future prospects.

By addressing the specific topic of adaptation in precarious prosperity, the study sheds light on aspects of adaptation that cannot be revealed by quantitative research and enables analyses of the mechanisms at play between subjective wellbeing and objective living conditions.

In the following section (2), I describe the conceptual framework that guides the research. The data and methods are presented in section 3. Section 4 depicts the empirical results relating to adaptation in a situation of precarious prosperity, and section 5 concludes the article.

\section{Agency and reasoning: The conceptual framework}

Before describing the conceptual framework for analysis, I will present a short list of some assumptions derived from the literature and the former results of research on precarious prosperity:

, In precarious prosperity, the QOL is assumed to be lower than it is in secure prosperity, due to limited income and experiences of deprivation (Budowski et al. 2010).

, People exercise agency to maintain or improve their QOL. In contrast, people who have adapted are considered as not to actively changeing their living conditions, because adaptation is associated with powerlessness and resignation (Olson and Schober 1993).

Zapf (1984) distinguishes 4 welfare positions by combining favorable or disadvantaged objective living conditions with high or low subjective well-being. According to this definition, adaptation describes the state of disadvantaged objective living conditions and high subjective well-being. It represents the "satisfaction paradox," or being satisfied with disadvantaged living conditions.

Table $1 \quad$ Welfare positions

\begin{tabular}{l|cc}
\hline Objective living conditions & \multicolumn{2}{|c}{ Subjective well-being } \\
& High & Low \\
\hline Favorable & Well-being & Dissonance \\
Disadvantaged & Adaptation & Deprivation \\
\hline
\end{tabular}

Source: Zapf (1984). 
I will refine Zapf's understanding of QOL and adaptation by the following elements:

' Adaptation is not necessarily a global state of the individual; it may concern only one or another specific life domain.

, The present analysis will stress the time component by departing from the state of adaptation and linking it to the processes leading to adaptation.

Lister's (2004) theoretical framework furnishes elements to address domain-specific agency and the time component. I consider her framework to be useful not only for poverty but also for precarious prosperity. Her aim is to focus "on the agency of individuals in poverty without losing sight of the ways in which their agency is constrained by lack of material resources and power" (Lister 2004, 127). In this sense, adaptation is not only an individual issue, as "movements in and out of poverty are a product of both individual actions (taken by poor and non-poor) on the one hand and economic and social processes and Government policies on the other" (Lister 2004, 145).

Lister (2004) distinguishes between "strategic" and "everyday" agency and between "personal" and "political/citizenship" agency (see Figure 1). In her framework, she identifies four kinds of agency:

, "Getting by" refers to everyday coping, such as making ends meet. I situate processes leading to adaptation by this type of agency because they affect the individual and concern short-term well-being: They help people to cope by improving subjective well-being. However, adaptation is only considered agency if people explain their constraints and how they adapt to them (according to Schütz [1932], see below).

, "Getting back at" refers to everyday resistance or rebellious behaviour (black labor, drug use, etc.). It has a political aspect in the sense that every day it shows where social policy measures do not correspond to the needs of households in precarious prosperity.

, "Getting out" refers to long-term agency to improve one's own living conditions. Typical types of "getting out" are education, receiving social benefits or pensions, and finding a better job.

"Getting organized" refers to collective strategic agency (political activities, collective self-help) and depends on a sense of identification as a member of a group (in precarious prosperity, migrants, retirees, etc.).

While Lister's framework allows for a better understanding of the types of agency, the sociology of knowledge perspective links agency theoretically to adaptation by referring to the sense and reasoning of the agent. According to Schütz, people's reasoning guides their actions, and the meaning they attribute to an action characterizes the action as an action (Schütz 1932). Similarly, people legitimize their actions to make sense of life events a posteriori. Making sense of actions occurs 
Figure 1 Framework of agency

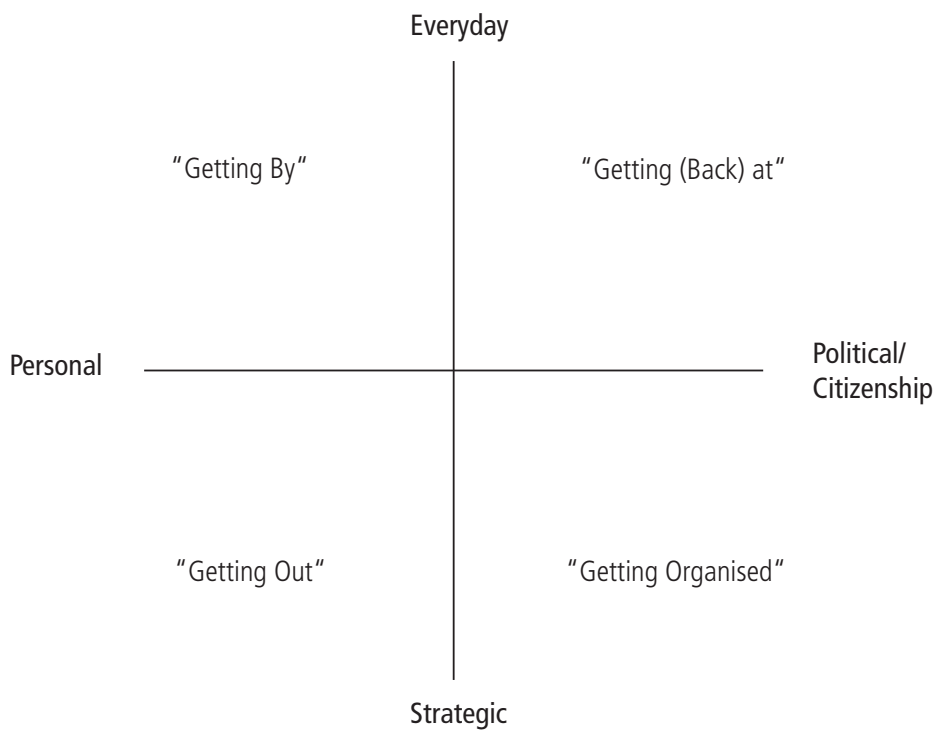

Source: Lister $(2004,130)$.

in a social context and is influenced by people's social interests (Jarvie 2016, 131). From this perspective, adaptation over time can be defined as agency. Combining Lister's framework and the perspective of Schütz allows for a conceptual framework to analyze adaptation in precarious prosperity over time.

\section{Methods}

This section first describes the available data and criteria for case selection for the analysis. Second, it explains the methodology of the data analysis.

\subsection{Description of data and case selection}

The data were gathered from two projects financed by the Swiss National Science Foundation. ${ }^{3}$ For this longitudinal analysis, three waves of qualitative semi-structured interviews with households in Switzerland were analyzed (2008, 2009, and 2013 in Bern, Lausanne, and Zürich, for 50 households altogether). The interviews were performed with one household member, an individual embedded in his or her household and the structural context. The interviewees were asked to talk about

$3 \quad$ Project information to be introduced here. 
their living conditions, and the data contain information about the individual and household situation (finances, work, education, health, environment, social network), the evaluation of this situation (quality of life), and the individuals' and the households' biographies and future prospects. Quantitative data on the living conditions of the households complete the qualitative interview data.

Households in precarious prosperity, identified by income and deprivation thresholds, were the target group for the interviews, and these were obtained by telephone screening in 2008. A household in precarious prosperity is defined as follows:

, having an equivalized household income in the range of $60-80 \%$ of the median income of the population of the country, or

, having an equivalized income below the $60 \%$ income-poverty threshold, yet not being deprived according to the deprivation threshold, or

, having an equivalized income above the $80 \%$ income-poverty threshold, yet being deprived by the deprivation threshold (Budowski et al. 2010).

For the first interview in 2008, all households were situated in the same welfare position between poverty and secure prosperity. The sample is heterogeneous in terms of household composition (singles, couples, families, flat sharing) and income sources (work income, old-age pension, invalidity pension, unemployment benefits, widow pension or other state support, or financial support from parents) in addition to age, profession, and origin of the household members. During the research period, some of the households experienced upward and some downward mobility, but many were still in precarious prosperity at the end of the five-year period (see Table 2). The focus of this analysis is on the households that were still or again in precarious prosperity at the time of the third interview (29 cases). ${ }^{4}$

For the analysis, households in which the interviewee was in a position of adaptation (according to Zapf's definition) at the time of the last interview in 2013 were identified (Table 2). The subjective well-being of the interviewee was evaluated based on the qualitative data. Some of the interviewees spontaneously reported their well-being in the overall evaluations (I am well, I am satisfied, I am not happy, etc.) or in evaluations linked to reports about life domains (health, work, social networks, etc.). If they did not speak about their subjective well-being, the interviewer asked the person to evaluate their life domains and how they felt in general. As the following table shows, the four welfare positions defined by Zapf have been specified (three categories of living conditions and three levels of well-being) for this analysis:

The analysis focused on the 18 cases in adaptation and the 3 contrast cases in deprivation. However, among the cases classified as "adapted," 6 were indeed in precarious prosperity in 2013, but they had improved their situation in some

$4 \quad$ It is beyond the scope of this article to analyze adaptation linked to improved living conditions or to poverty and to compare households in precarious prosperity with those in another socioeconomic status. 
Table 2

Interviewees in 2013, according to living conditions and subjective well-being

\begin{tabular}{|c|c|c|c|}
\hline \multirow{2}{*}{$\begin{array}{l}\text { Living conditions } \\
\text { of the household } 2013\end{array}$} & \multicolumn{3}{|c|}{ Subjective well-being of the interviewee 2013} \\
\hline & High & $\begin{array}{c}\text { Middle } \\
\text { (or domain specific } \\
\text { high and low) }\end{array}$ & Low \\
\hline Secure prosperity & $\begin{array}{l}\text { "Well-being" } \\
\text { (8 cases) }\end{array}$ & $\begin{array}{c}\text { "Partial well-being" } \\
\text { (3 cases) }\end{array}$ & $\begin{array}{l}\text { "Dissonance" } \\
\text { (3 cases) }\end{array}$ \\
\hline Precarious prosperity & $\begin{array}{l}\text { "Adaptation" } \\
\mathrm{CH} 44, \mathrm{CH} 11, \mathrm{CH} 12, \\
\mathrm{CH} 15, \mathrm{CH} 20, \mathrm{CH} 25, \\
\mathrm{CH} 27, \mathrm{CH} 32, \mathrm{CH} 33, \\
\mathrm{CH} 42, \mathrm{CH} 43, \mathrm{CH} 44, \\
\mathrm{CH} 47, \mathrm{CH} 54, \mathrm{CH} 55, \\
\mathrm{CH} 58, \mathrm{CH} 71, \mathrm{CH} 72\end{array}$ & $\begin{array}{c}\text { "Partial adaptation" } \\
\mathrm{CH} 03, \mathrm{CH} 17, \mathrm{CH} 21, \\
\mathrm{CH} 24, \mathrm{CH} 45, \mathrm{CH} 51, \\
\mathrm{CH} 64, \mathrm{CH} 69\end{array}$ & $\begin{array}{c}\text { "Deprivation" } \\
\text { CH07, CH37, CH61 }\end{array}$ \\
\hline Poverty & $\begin{array}{l}\text { "Adaptation" } \\
\text { (1 case) }\end{array}$ & $\begin{array}{c}\text { "Partial adaptation" } \\
\text { ( } 2 \text { cases) }\end{array}$ & $\begin{array}{l}\text { "Deprivation" } \\
\text { (4 cases) }\end{array}$ \\
\hline
\end{tabular}

Source: Own illustration, oriented by Zapf (1984).

life domains, and thus their situation was characterized by dynamics of improving living conditions. Among these cases, no reasoning or processes of adaptation were observed (CH32, $\mathrm{CH} 44, \mathrm{CH} 54, \mathrm{CH} 55, \mathrm{CH} 58, \mathrm{CH} 71)$.

\subsection{Method of analysis}

Adaptation processes occur over time and must be analyzed by a longitudinal research design. To be precise, qualitative longitudinal research allows for analyzing the change or continuity of the households' living conditions and the interviewees' subjective well-being, agency, and reasoning (Holland 2011). The selected households' socioeconomic positions were identified as precarious prosperity at the beginning and end of the research period. The qualitative interviews provided information on the changes that occurred in specific life domains and regarding the opportunity structures between the interviews, even if the household remained in the socioeconomic position of precarious prosperity across the time period. The interviewee who adapted to the conditions of precarious prosperity presented and discussed a high subjective well-being at the time of the third interview, yet subjective well-being differed between cases in the beginning. The analysis focused on the interviewees maintaining or improving QOL during the data-collection period and extended, to a minor degree, beyond the time of the data-collection period in that past experiences (personal and household biography) and households' and individuals' future anticipations were also considered in the understanding of their QOL (MacKie et al. 2002). I analyzed the evolution of the QOL and adaptation by means of thematic charts (Ritchie et al. 2003). Elaborated for each case and each 
year, such charts enable the analysis of QOL by case, its evolution over time, and the comparison of cases and their evolution. The thematic charts reveal recurrent reasonings as well as links to living conditions that allow for identifying the four types of adaptation presented in 4.2 .

Household information is necessary, as individuals are contextually embedded, and their QOL extends beyond individual issues. However, methodologically, after having selected the cases according to living conditions, the analysis was carried out without taking living conditions and the household situation of the interviewees into account in the first step. In doing so, it was possible to lower the influence of the researcher's preconceptions about what social experiences are relevant for the reasonings of adaptation. In a second step, the link between agency and reasoning with the respective living situations was made to explain the social conditions and experiences leading to it. Finally, I focused on the way in which precarious living conditions influenced change or continuity as well as on the agency of all the household members (Saldaña 2003).

\section{$4 \quad$ Results}

The research question was approached first by means of an analysis of the individual's agency and its evolution over time in order to reveal the link between adaptation and agency in precarious prosperity. Second, the reasoning about adaptation was further investigated.

\subsection{Adaptation and agency}

According to the assumption that adaptation accompanies powerlessness and resignation, one might expect that people in a state of adaptation are no longer actively improving their household's living conditions. The analysis of agency showed that all adapted interviewees implemented other kinds of agency, and thus, the processes leading to adaptation did not lead to complete resignation. However, when other kinds of agency failed to improve the situation for the interviewee, domain-specific resignation linked to domain-specific adaptation was observed. Applying Lister's (2004) framework, the following two cases disclose, in an exemplary way, the interplay of agency and adaptation. These cases were chosen as exemplary because they allow for the illustration of various aspects of adaptation.

CH11 was a woman in her fifties. She had been living with her husband in 2008 and 2009 and with her husband and adult daughter in 2013. She worked at night as a nurse in a home for the elderly. The family faced several challenges linked to health problems: The husband was addicted to alcohol, the daughter had psychological troubles linked to sexual abuse in her childhood, and the interviewee was suffering from a non-curable autoimmune disease causing tiredness, fever, aches, 
and other symptoms (lupus). The main agency reported by the interviewee concerned problems in the domain of health and work, as Table 3 shows in greater detail:

Table 3

Agency over time $\mathrm{CH} 11$

\begin{tabular}{l|l|l|l|l}
\hline CH11 & Getting by & Getting out & Getting back (at) & Getting organized \\
\hline 2008 & & $\begin{array}{l}\text { Apply for invalidity pension, } \\
\text { psychological and financial } \\
\text { support of the daughter } \\
\text { Waiting for invalidity pension, } \\
\text { support of the daughter }\end{array}$ & $\begin{array}{l}\text { Social comparison, } \\
\text { holiday at their } \\
\text { friend's house to } \\
\text { reduce expenses } \\
\text { Reappraisal, } \\
\text { going to Hungary for } \\
\text { cheaper dental care }\end{array}$ & $\begin{array}{l}\text { Standing in } \\
\text { opposition at work } \\
\text { Self-help groups }\end{array}$ \\
$\begin{array}{l}\text { Support of the daughter, } \\
\text { looking for paramedical } \\
\text { support to complete her } \\
\text { health care }\end{array}$ & & Self-help groups \\
\hline
\end{tabular}

On the one hand, this woman actively tried to improve the psychological and physical well-being of all family members during the research period. During the interview period, she applied for invalidity pension with success, leading to greater financial stability for the household and the relieving of financial stress. On the other hand, she stopped the activities that aimed to improve her working conditions between 2008 and 2013. Her resignation and adaptation to her work situation came to the forefront in the interviews when comparing her reports on work over time.

I dare to shout at my workplace when I need to. If they listen to me is another question. (CH11, 2008)

At the beginning, I stood in opposition, yes (...) but as they are strict and (pff), the management took it bad (...) it's (pff) niet, "if you are not happy, you can go elsewhere." That's clear. So, I don't lose my energy in fighting for this (...) I try to do my work according to the values that are important for me within the scope of action I have. $(\mathrm{CH} 11,2013)$

She also adjusted her perspectives on the future, especially connected to her daughter's situation. In contrast with the work domain, the adaptation in this life domain did not accompany resignation, as she still continued to support her daughter psychologically and financially. This represented a type of mental aid that helped her persevere, as her daughter's work situation was worsening (she had lost her job and had not find an apprenticeship) and had returned home to live with her parents. This kind of adaptation came to the fore when she was asked about her plans and wishes for the next five years at each interview: 
I hope that my daughter will soon be independent and that we won't have to support her financially anymore. (CH11, 2008)

I don't want to foresee to the future and plan something. It's more likeexperience what we have to experience and we'll see. I think I would rather make bad foresights for the future, so I prefer not to imagine anything. (...) I've enough to do today (laughing); my future perspectives go only until this evening. (CH11, 2013)

On the one hand, the case of this woman showed an ongoing process of adaptation in the domains of work and care during the research period. Resignation seemed to be appropriate to describe what was happening in the work domain, because she had stopped every kind of agency to improve her working conditions. In the domain of care (in particular expressed through the future perspectives), she seemed to adapt to obtain more emotional distance and better care for herself, but she still continued other kinds of agency in this domain. Therefore, this adaptation could not be interpreted as resignation. On the other hand, she continued to actively change her living conditions in the financial and health domains.

The second case (CH43) is a man in his fifties. He was living with his wife in 2008 and 2009 and alone (after their separation) in 2013. His work situation was not stable; he worked mainly as an actor and supplemented his income by working temporarily as a painter. His reported agency is listed in Table 4.

Table 4

Agency over time $\mathrm{CH} 43$

\begin{tabular}{|c|c|c|c|c|}
\hline $\mathrm{CH} 43$ & Getting by & Getting out & Getting back (at) & Getting organised \\
\hline 2008 & $\begin{array}{l}\text { Being used to live with little } \\
\text { money, temporary jobs }\end{array}$ & $\begin{array}{l}\text { Contributions to a special } \\
\text { pension pool for artists }\end{array}$ & & \\
\hline 2009 & $\begin{array}{l}\text { Being used to live with little } \\
\text { money, working as an } \\
\text { independent painter }\end{array}$ & $\begin{array}{l}\text { Contributions to the } \\
\text { pension pool, looking for } \\
\text { a new job as actor }\end{array}$ & & \\
\hline 2013 & $\begin{array}{l}\text { Getting used to social } \\
\text { assistance, working as } \\
\text { an independent painter, } \\
\text { cultivating vegetables in his } \\
\text { garden, changing the health } \\
\text { insurance every year }\end{array}$ & $\begin{array}{l}\text { Contributions to the } \\
\text { pension pool, applying for } \\
\text { social benefits between } \\
\text { periods of work, waiting } \\
\text { for early retirement }\end{array}$ & & $\begin{array}{l}\text { Offering himself as } \\
\text { a candidate for the } \\
\text { city assembly }\end{array}$ \\
\hline
\end{tabular}

This man spoke explicitly about adaptation in all the interviews. As an actor, he had always had to deal with insecurities linked to his work situation and low income. "It is not hardship, you rather just get through, well, I am actually used to this" (CH43, 2008). 
As the respondent's presentation of his biography revealed, the process of adaptation had already started before we interviewed him and had led to a state of adaptation across all life domains (high overall and domain specific well-being despite insecure and low income, difficulties finding work, problems in his relationship, and unsuccessful political activity). Moreover, one can observe how the interviewee once more changed his agency, which was accompanied by adaptation processes, during the research period to avoid slipping into poverty. This adaptation concerned his attitude toward social benefits. When he still lived together with his wife, they were able to compensate for a temporary lack of income mutually, and in the first interviews, he could not imagine receiving social benefits:

If I had nothing left, I would have to go to the social benefits office. (...) I rather go cleaning roads, cleaning somewhere, anywhere, it doesn't matterbut I don't want this [social benefits]. But I think this will never happen. (CH43, 2008)

In 2013, living alone, he accepted social benefits to overcome periods of unemployment and adapted to this new situation: "Well, as an actor I am always muddling through a little bit, and then I have, ahm, in between I just have to go to the social benefits office, but this is nothing special to me. It is, ehm, it is just like that" (CH43, 2013).

This case shows the result of a longer lasting adaptation process linked to the specific work situation, which still continues to affect current events in the household. In the interviewee's reasoning, adaptation was not presented as resignation, but seemed to be an internalized attitude that allowed for dealing with ongoing insecurities. This man also presented his precarious work situation as a choice, a source of well-being, and, respectively, self-realization. He further exercised other kinds of agency in the financial, work, and political domain.

Comparing the two cases, the main differences appear in the element of choice: CH11 seemed to be constrained by her care responsibilities and the diverse health problems in her family. CH43 presented himself as free and independent. This difference could either be due to effective differences in the living conditions or to a more advanced process of adaptation in the case of $\mathrm{CH} 43$ (see 4.2.5). The two cases had in common the fact that while they were both adapting, the interviewees continued to exercise agency in some life domains. This is the first element that also emerged in all other cases, despite very diverse household situations and the complex interplay between living conditions in different life domains. Furthermore, all cases in precarious prosperity presented reasoning on adaptating, even those with low subjective well-being. The processes leading to adaptation may thus be interpreted as an agency of "getting by" (Lister 2004).

What distinguished the three cases with low subjective well-being (CH07, $\mathrm{CH} 37, \mathrm{CH} 61)$ from the others is that they explained how they were able to adjust 
and adapt to a situation to a certain extent, but that the deprivations could not be addressed in a positive way any longer when they became too important. In all of these cases, mainly severe health problems caused the low QOL, which spilled over into all other life domains. "What do you want? You have to lower your expectations, but I am less and less able to cope with this because I have to lower my prospects too much" (CH37, 2013).

Second, the interviewees exercise agency mainly on a personal or household level (getting by, getting out). Only a few reported collective agency, and when the agency of "getting organized" occurred, it was not linked to a sense of belonging to precarious prosperity (or other terms describing their socioeconomic position) but to health problems or a specific profession, for instance.

When observing agency, it is important to understand that adaptation does not equal overall resignation. Moreover, the feeling of powerlessness or lack of agency is rather domain-specific and is observed at an earlier stage of adaptation. The next section will go into more depth about reasoning over time to provide a more complete understanding of what is happening in processes leading to adaptation.

\subsection{Reasoning for adaptation}

Some of the interviewees in 2013 spoke explicitly about adaptation ("s'adapter», «sich anpassen»: $\mathrm{CH} 12, \mathrm{CH} 15, \mathrm{CH} 33, \mathrm{CH} 42)$. Going beyond this explicit discourse allowed for an analysis of the reasoning linked to high subjective well-being, despite being in precarious prosperity. In fact, high subjective well-being was explicitly explained by all interviewees in precarious prosperity, even if there was no question about the reason for SWB in the interviews. Hence, well-being was not self-evident to them, and they referred to various processes and social experiences to explain it. The interviewees' statements about how they adapted allowed for the identifying of types of adaptation reasoning. Three of these types can also be found in psychological literature: Social comparison (Festinger 1954), diminution of aspirations (Lewin et al. 1944), emotional detachment (term of the author), and reappraisal (Sirgy 2002). The analysis does not focus on personality traits to explain why and how people adapt, but on social experiences (relevant life events or situations that reach beyond the individual) which could explain these types of adaptation. Interestingly, when looking at the biographies, household situations, and different life domains of the interviewees, there was a coincidence of specific social experiences and types of adaptation across the cases. Combining reasonings and social experiences allowed for the developing of patterns of adaptation. In the sample, one person generally referred to several processes and types of adaptation. One person may also have encountered several of the social experiences described in the following section (e. g., a mother caring for her children who had immigrated to Switzerland). Thus, the four patterns of adaptation presented here must be seen as phenomena and can accumulate in some cases. 


\subsubsection{Social comparison and migration}

The first type of adaptation occurs through social comparison (Festinger 1954) and means that people evaluate their own QOL by comparing it with that of others. Social comparison was often drawn upon in the analyzed sample. The interviewees compared themselves to those with worse health problems, to families with care responsibilities, and so on (e.g., CH33). However, social comparison seemed to be particularly crucial for subjective well-being when people immigrated to Switzerland from a country clearly characterized by lower living conditions, such as Colombia (CH15), Chile (CH20), or Tibet (CH71). Actually, all people interviewed from such countries strongly referred to their origins in comparison to Switzerland as a frame of reference when evaluating their QOL. This led to a positive perception of their actual living conditions and to high subjective well-being.

I come from another country where it changed every day: We had the coup d'etat, we had earthquakes. (...) I'm so used to starting from scratch that all the changes you have here don't really change anything for me. (...) I think, compared to other countries where children live on the street (...), here in Switzerland you don't have that. (...) Here, there is always help-you can always count on something. (CH20, 2013)

\subsection{2 "Getting used to," changing aspirations, and precarious work}

A second type of adaptation to precarious prosperity could be identified in the sample, and it involved getting used to a situation or learning to deal with difficulties, leading to a diminution of stress and negative feelings over time. This process went along with the diminution of aspirations (see Lewin et al. 1944) and a demarcation from others who were not accustomed to precariousness (those who had not been in precarious working conditions for a longer period and those who needed to have money to buy things). A dissociation from the norm of stability and consumer society was observed in these cases. For interviewees involved in this type of process, the processes of adaptation had begun before the research period; this can be considered the reason why the interviewees reported high subjective well-being in all three interviews, despite worsening living conditions (e.g., loss of a job, CH42). Actually, in the sample, this type of adaptation was linked to a precarious work situation over at least five years (see also case study CH43).

[Financial insecurity] did not stress me so much. Oh, sure, it is sometimes uncomfortable, but in fact I have always - what shall I say - my life hasn't run in straight lines, so that this didn't scare me. (CH03, 2013)

People don't like to renounce. They want to have everything, and this is expensive. (...) You have to set goals you know you will be able to attain. It's like that, and then you don't have problems, I think. (...) We couldn't 
be happier, even if we had I don't know how much money on our accounts every month. (CH42, 2013)

\subsubsection{Being on your own and care responsibilities}

A third type of adaptation process in the sample involved the interviewees reasoning with their own resources to address their situation. The reasoning concerned being on one's own to manage one's life and taking one's own responsibility for better subjective well-being:

If I look at the negative, then it is very bad: oh, I am alone, I have to work all day and then there is my son and then... If I think positive, I am satisfied. I think: oh, I am strong enough, I did this like that, I made it myself, I organized this. I am proud, if I think positive. $(\mathrm{CH} 71,2009)$

Looking at the interviewees' household situation with this reasoning, we can see that they all were women with children (teenagers and young adults) in the household and that they cared for the problems of the other household members (health, education, integration into the labor market). Reasoning such as "it's up to you" and "you have to detach" seemed to be linked to the experience of having no help from others in relation to their household needs: They complained about the welfare state's and community's lack of support for families and explained how they bore multiple burdens for their households. During the research period, the analysis revealed an ongoing process of emotional detachment leading to higher subjective well-being, despite stable or worsening living conditions (see also case study CH11).

\subsubsection{Reappraisal after experiencing health problems}

Finally, an interesting link was found between the experience of health problems and adaptation. The importance of health for QOL in precarious prosperity has already been discussed (Budowski et al. 2016). Adaptation to precarious living conditions seemed to be possible in this study's sample when the people who experienced the health problems were (at least partially) cured or stable. In these cases, the interviewees relativized the difficulty of their living conditions in light of the health difficulties they had had in the past (reappraisal).

It is changing a little bit. Well, you have wishes and stuff, but that's all. Well, perspectives are changing with this disease. You tell yourself health first, that's the most important; isn't it? This has changed; there was a little bit of a turnaround. (CH47, 2009)

In contrast, the three cases who lived in a situation of deprivation linked their low subjective well-being directly to their health problems. Interestingly, they had a similar reasoning as those who were adapted, but it was the opposite, e. g., $\mathrm{CH} 37$ was suffering from a chronic muscle disorder and discussed social comparison: 
I have great difficulty with people of my age because I get really jealous. I'm sorry to say this; it is bad because I compare myself to them. (CH37, 2013)

\subsubsection{Reasoning over time}

When comparing these four types of cases with regard to adaptation, living conditions, and subjective well-being over time, there was an interesting evolution in the reasoning of the people: Among the cases in which a process to adaptation could be observed within the research period (mainly those with care responsibilities and those who had experienced health problems), the reports of their overall well-being were more positive than what they said about specific life domains in the rest of the interview (see also case study CH11). In these interviews, people told us they were doing well and were satisfied, but between the lines, I could hear another story. They actually corrected themselves, or rather, they persuaded themselves that they were well. There seemed to be a perceived norm of being satisfied in their situation (or no reason to be unsatisfied), even if they experienced difficulties in some life domains.

I must not complain. I am well, apart from the little aches and pains one has at my age, right? Slowly but surely, everything takes more time. What do you want? (...) No, I have to be satisfied. And as long as I am able to walk, well, I am satisfied; then I don't want to complain (...) No, now I am actually satisfied; yes, I am well, and if my health stays as it is, I must not complain, if it doesn't get worse. Let's be satisfied and make the best of it. $(\mathrm{CH} 33,2013)$

In contrast, the interviewees whose processes to adaptation had been ongoing for a longer period of time (before 2008) do not correct themselves (mainly the immigrants and those with a biography of precarious work). Rather they explained that they were "lucky" and were aware of their luck.

I think I am rather well because I am very aware of all the luck I have, in fact, to, to - I have friends, I am in good health, I have a great flat, I have a job where I work at home when I want at the time I want. Well, this is liberty, it is an extraordinary luxury - so I am rather, rather well. (CH04, 2013)

As illustrated in the case of $\mathrm{CH} 43$, they seemed to have internalized the norm of being satisfied and totally identified with it. They also distanced themselves from "the others" who had more money and liked to buy things, by explaining that they did not need that many material goods. "We are not people who change the furniture all the time, who change, ehm, for nothing, or who buy clothes all the time" (CH17, 2013, day nanny).

In summary, the explanations for adaptation seemed to be linked to a perceived norm to be satisfied and referred to social comparison (migration), "getting used to a situation" and lowering aspirations (precarious work), stressing one's own resources 
and emotional detachment (care), and reappraisal (health). The associated social experiences shed light on a possible link between living conditions and adaptation. Moreover, a process of internalization over time could be identified, which showed up in a changing discourse about subjective well-being: the longer the adaptation process had been occurring, the less incoherent was the information given by the interviewees concerning their living conditions and respective well-being.

\section{Conclusion}

Quantitative research has challenged the existence of adaptation, while qualitative research on the topic is rare and has associated adaptation with powerlessness and resignation. This paper is based on an analysis of adaptation in precarious prosperity over time and aimed to explain how adaptation occurs. It investigated the processes leading to a state of adaptation (high subjective well-being despite precarious prosperity, according to Zapf [1984]) using a longitudinal qualitative design. Lister's (2004) framework on agency allowed for an analysis of the processes of adaptation as agency among other kinds of agency. These processes are understood here as agency, or as the interviewees' reason about it, even in cases with low SWB. The sociology of knowledge approach (Schütz 1932) was also applied to delve into the interviewees' reasoning.

The results show that adaptation is, first, domain specific and occurs in parallel with other kinds of agency. The specific processes of adaptation tend to be similar according to what people perceive as relevant social experiences - a link that should be confirmed in future research: social comparison was common among people who immigrated to Switzerland from another country with lower living conditions. "Getting used to a situation" and lowering aspirations came to the fore after longer lasting precarious living conditions (e. g., precarious work). Emotional detachment and relying on one's own resources seemed to be a way to "get by" when people had care responsibilities in the household, and reappraisal occurred in general after (at least partially) cured health problems. Incidentally, severe health problems were also the main reason hindering adaptation and leading to low subjective well-being in precarious prosperity.

The interviewees seemed to perceive high subjective well-being as the norm, but it was not self-evident to them and was thus explained. However, their reasoning changed over time and revealed a process of internalization of the perceived norm to be satisfied: the longer the adaptation process had been going on, the less the interviewees gave incoherent information and self-correcting reports concerning living conditions and respective well-being. Although the interviewees perceived resignation in the beginning of the process of adaptation (when other kinds of agency had been unsuccessful), precarious living conditions were indeed presented 
as normal or even as a choice in a later stage of the process. The state of adaptation spilled over from one life domain into others and into general subjective well-being.

Looking at subjective well-being alone thus presents a distorted picture when evaluating welfare. Adaptation must be taken into consideration when looking at the QOL of people and households in precarious prosperity. This paper contributes to the understanding of how QOL is affected by adaptation. It helps people on an individual level to get by and care for their households. At the same time, the results support Graham's statement about the risk of lower welfare levels relating to adaptation (Graham 2009, 215) while adding insight about the risk of the reproduction of inequalities on a societal level to it, in the sense that adaptation does not encourage redistribution processes via the welfare state; the analysis shows that adaptation does not accompany political agency and change but rather stability of living conditions and individual welfare.

\section{References}

Appadurai, Arjun. 2004. The Capacity to Aspire. Pp. 59-84 in Culture and Public Action, edited by Vijayendra Rao and Michael Walton. Washington DC: The World Bank.

Bankoff, Gregory. 2001. Rendering the World Unsafe: "Vulnerability" as Western Discourse. Disasters 25(1): 19-35.

Budowski, Monica, Sebastian Schief, and Rebekka Sieber. 2016. Precariousness and Quality of Life - a Qualitative Perspective on Quality of Life of Households in Precarious Prosperity in Switzerland and Spain. Applied Research Quality Life 11: 1035-1058.

Budowski, Monica, Robin Tillmann, Wiebke Keim, and Michèle Amacker. 2010. Conceptualising "Precarious Prosperity" - Empirical and Theoretical Elements for Debate. International Journal of Comparative Sociology 51(4): 268-288.

Castel, Robert and Klaus Dörre (eds.). 2009. Prekarität, Abstieg, Ausgrenzung - Die soziale Frage am Beginn des 21. Jahrhunderts. Frankfurt/M: Campus.

Crettaz, Eric and Christian Suter. 2013. The Impact of Adaptive Preferences on Subjective Indicators: an Analysis of Poverty Indicators. Social Indicators Research 114: 139-152.

Easterlin, Richard. 1974. Does Economic Growth Improve the Human Lot? Some Empirical Evidence. Pp. 89-125 in Nations and Households in Economic Growth: Essays in Honor of Moses Abramovitz, edited by Paul. A. David and Melvin. W. Reder. New York: Academic Press.

Elster, Jon. 1982. Sour Grapes, Utilitarianism and the Genesis of Wants. Pp. 210-238 in Utilitarianism and Beyond, edited by Amartya Sen and Bernard Arthur Owen Williams. Cambridge: Cambridge University Press.

Farago, Peter, Petra Hutter Király, Beat Brunner, and Christian Suter. 2005. Prekäre Lebenslagen. Subjektive Bewertungen und Handlungsstrategien in Haushalten mit knappen finanziellen Ressourcen. Forschungsbericht 2/05. Bern: Bundesamt für Sozialversicherungen.

Felce, David and Jonathan Perry. 1995. Quality of Life: Its Definition and Measurement. Research in Developmental Disabilities 16(1): 51-74.

Festinger, Leon. 1954. A Theory of Social Comparison Processes. Human Relations 7: 117-140.

Graham, Carol. 2009. Happiness Around the World. Oxford: Oxford University Press. 
Grimm, Natalie, Andreas Hirseland, and Berthold Vogel. 2013. Die Ausweitung der Zwischenzone. Erwerbsarbeit im Zeichen der neuen Arbeitsmarktpolitik. Soziale Welt 64: 249-268.

Helson, Harry. 1964. Adaptation-Level Theory. New York: Harper \& Row.

Helvik, Anne-Sofie, Valentina Cabral Iversen, Randi Steiring, and Lillemor R.-M. Hallber. 2011. Calibrating and Adjusting Expectations in Life: A Grounded Theory on How Elderly Persons With Somatic Health Problems Maintain Control and Balance in Life and Optimize Well-Being. International Journal of Qualitative Studies on Health and Well-Being 6: 1-12.

Holland, Janet. 2011. Timescapes: Living a Qualitative Longitudinal Study. Forum Qualitative Social Research 3, http://www.qualitative-research.net/index.php/fqs/article/view/1729 (05.09.2016).

Hübinger, Werner. 1996. Prekärer Wohlstand: Neue Befunde zu Armut und sozialer Ungleichheit. Freiburg i. Br.: Lambertus.

Jarvie, Ian C. 2016. Concepts and Society. London: Routledge.

Lewin, Kurt, Tamara Dembo, Leon Festinger, and Snedden Sears. 1944. Level of Aspiration. Pp. 333-378 in Personality and the Behaviour Disorders. A Handbook Based on Experimental and Clinical Research, edited by Joseph McV. Hunt. New York: The Ronald Press.

Lister, Ruth. 2004. Poverty (Key Concepts). Cambridge: Polity Press.

MacKie, Linda, Susan Gregory, and Sophia Bowlby. 2002. Shadow Times: The Temporal and Spatial Experiences of Caring and Working. Sociology 36(4): 897-924.

Mayer, Arno J. 1975. The Lower Middle Class as Historical Problem. The Journal of Modern History 47(3): 409-436.

Noll, Heinz-Herbert. 2002. Social Indicators and Quality of Life Research: Background, Achievements and Current Trends. Pp. 151-181 in Advances in Sociological Knowledge Over Half a Century, edited by Nicolai Genov. Paris: International Social Science Council, http://www.gesis.org/fileadmin/ upload/institut/wiss_arbeitsbereiche/soz_indikatoren/Publikationen/isscnoll.pdf (05.09.2016).

Noll, Heinz-Herbert. 1999. Konzepte der Wohlfahrtsentwicklung: Lebensqualität und «neue» Wohlfahrtskonzepte. EuReporting Working Paper No. 3. Centre for Survey Research and Methodology (ZUMA), Mannheim.

Olson, Geraldine I. and Brigitte I. Schober. 1993. The Satisfied Poor: Development of an InterventionOriented Theoretical Framework to Explain Satisfaction With a Life in Poverty. Social Indicators Research 28(2): 173-193.

Piper, Alan T. 2014. Zukunftsangst! Fear of (and Hope for) the Future and Its Impact on Life Satisfaction. Munich Personal RePEc Archive. Europa-Universität Flensburg, https://mpra.ub.uni-muenchen. de/59557/1/MPRA_paper_59557.pdf (01.04.2016).

Ray, Debraj. 2003. Aspirations, Poverty and Economic Change. New York: New York University and Instituto de Analisis Economico (CSIC).

Ritchie, Jane, Liz Spencer, and William O'Connor. 2003. Carrying out Qualitative Analysis. Pp. 219-262 in Qualitative Research Practice: A Guide for Social Science Students and Researchers, edited by Jane Ritchie and Jane Lewis. London: Sage Publications.

Saldaña, Jonny. 2003. Longitudinal Qualitative Research: Analyzing Change Through Time. Blue Ridge Summit, PA: Altamira Press.

Schulte, Katja. 1999. Die zeitliche und soziale Struktur von Einkommensarmut. Eine Neubetrachtung auf der Basis einer qualitativen Auswertung des sozio-ökonomischen Panels. Zentrum für SozialpolitikArbeitspapier Nr.5/99. Universität Bremen.

Schütz, Alfred. 1932. Der sinnhafte Aufbau der sozialen Welt. Eine Einleitung in die verstehende Soziologie. Wien: Springer.

Sieber, Rebekka and Ionela Vlase. 2016. Amélioration de la qualité de vie à partir de la prospérité précaire. Analyse du rôle des liens sociaux et des stratégies d'adaptation des ménages en Roumanie et en Suisse. Romanian Sociology 14(1): 61-74. 
Sirgy, Joseph M. 2002. The Psychology of Quality of Life. The Netherlands: Kluwer Academic.

Stiglitz, Joseph E., Amartya Sen, and Jean-Paul Fitoussi. 2009. Report by the Commission on the Measurement of Economic Performance and Social Progress, http://www.insee.fr/fr/publications-et-services/dossiers_web/stiglitz/doc-commission/RAPPORT_anglais.pdf (01.03.2016).

Tillmann, Robin and Monica Budowski. 2004. La pauvreté en Suisse. Pp. 29-53 in «Vivre en Suisse 1999-2000». Une année dans la vie des ménages et familles en Suisse, edited by Erwin Zimmermann and Robin Tillman. Bern: Lang Verlag.

Tillmann, Robin, Maurizia Masia, and Monica Budowski. 2016. Pauvreté, prospérité et bien-être en Suisse. Pp. 166-184 in Rapport Social 2016: Bien-être, edited by Franziska Ehrler, Felix Bühlmann, Peter Farago, François Höpflinger, Dominique Joye, Pascualina Perrig-Chiello, and Christian Suter. Zürich: Seismo.

Veenhoven, Ruut and Floris Vergunst. 2012. The Easterlin Illusion. Economic Growth Does Go with Greater Happiness. Paper presented at the $11^{\text {th }}$ Conference of the International Society for Quality Of Life Studies (ISQOLS). Venice, Italy.

Zapf, Wolfgang. 1984. Individuelle Wohlfahrt: Lebensbedingungen und wahrgenommene Lebensqualität. Pp. 13-26 in Lebensqualität in der Bundesrepublik. Objektive Lebensbedingungen und subjektives Wohlbefinden, edited by Wolfgang Glatzer, and Wolfgang Zapf. Frankfurt: Campus. 